\title{
METHODOLOGICAL APPROACH TO RESEARCH AND EVALUATE THE MAIN STATES AND TRANSITIONS ON THE LABOR MARKET
}

\author{
Venelin Terziev \\ Academician of the Russian Academy of Natural History, Moscow, Russia, \\ Prof. D.Sc. (Ec.), D.Sc. (National Security), D.Sc. (Social Activities), Ph.D., National Military \\ University, Veliko Tarnovo, Bulgaria; University of Rousse, Rousse, Bulgaria, terziev@skmat.com
}

\begin{abstract}
The focus of this approach is on the evaluation of the probability of transition or maintaining a certain state. By its implementation, additional possibilities for analysis and for taking the appropriate management decisions in the labor market are demonstrated.
\end{abstract}

Keywords: transitions, labor market, employment, unemployment, employers.

\section{INTRODUCTION}

The studies of the labor market are characterized by high interest from research and practical perspective. A number of approaches are applied depending on the preliminary determined goals. In this case, an approach for research of the labor market is presented, based on the assessment of the emerging major states and transitions. In the basis of the applied approach lies the already exposed concept of the three possible states in which a person of working age could be - employment, unemployment and economic inactivity. Between these three states six major flows are formed, which evaluation could be presented by the corresponding probabilities for transition.

\section{METHODOLOGICAL APPROACH TO RESEARCH AND EVALUATE THE MAIN STATES AND TRANSITIONS ON THE LABOR MARKET}

Switzerland can be considered as a classic example of a federal state. The three-level system of territorial In evaluating the probabilities of transition, we will follow the methodological approach, based on which the transitions between the states on the labor market are considered as a Markov process. This is a stochastic process in which the state at the time $t+1$ depends only on the state at the time $t$. The basis of such an approach is associated with research from the 70-s of Hall, Marston and others who consider the transitions between the states of the labor market, namely as a Markov process. As early as 1976 Marston presents a Markov model of the main flows of the labor market and evaluates the indicator of unemployment equilibrium through the probabilities of transition between the different states.

Wayne notes that the use of information on the transitions in the labor market enables the explanation of the differentiation of the unemployment ratios between the different groups. This creates an opportunity to develop different policies concerning the structural changes in the unemployment and the specific reasons 
for this, which can be explained on the basis of the transitions in the labor market. For example, the author's studies show that in case of unemployment caused by insufficient demand, the probability of transition from employment to unemployment increases and the probability of transition of the population outside the labor force or unemployment to employment decreases (Georgiev, 2016; Georgiev, 2017-a).

Very important for the development of this approach are also the published papers of Clark and Summers59, Poterba and Summers, and others. Based on this approach studies are carried out concerning the impact of the level of the unemployment benefits 59 on the states and transitions in the labor market, on the age and gender aspects of development of the states and transitions, etc.

In the last decade of $X X$ the studies through Markov models on the transitions in the labor market in Eastern Europe expand. For example in 1997, Mark Foley analyzes the transitions in the labor market in Russia, and Bell in 2000 - in Poland.

In our country, certain aspects of the transitions in the labor market are studied by Mariana Kotseva, Vasil Tsanov, Hristo Maleshkov and others, but there are no comprehensive and complete studies of the considered approach yet.

We use the basic principles and logic of this approach by applying it on the adopted concept of states and transitions in the labor market and the information on the labor force in Bulgaria.

For the purposes of this approach and the evaluations made by it, we assume that there are three basic states differentiated on the labor market: employment $(E)$, unemployment $(U)$ and economic inactivity $(N)$.

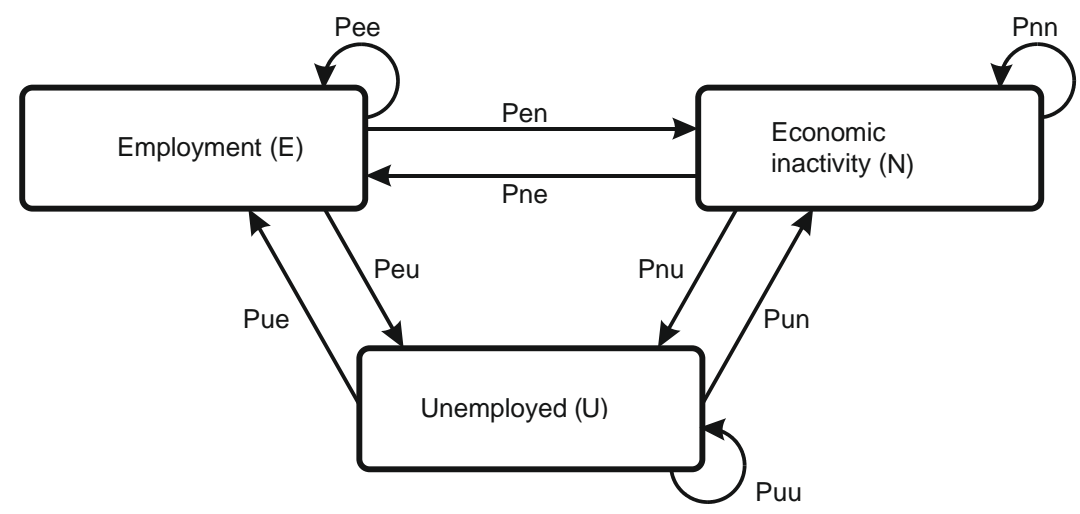

Fig.1. Main states and transitions in the labor market

Fig. 1 shows the main six transitions between the three main states, where:

- Pen is the probability of transition from the state of "employment" to the state of "economic inactivity" in a given period;

- Pne - probability for transition from the state of "economic inactivity" to the state of "employment" in a given period;

- Peu - probability for transition from the state of "employment" to the state of "unemployment" in a given period;

- Pue - probability for transition from the state of "unemployment" to the state of "employment" in a given period;

- Pnu - probability for transition from the state of "economic inactivity" to the state of "unemployment" in a given period;

- Pun - probability for transition from the state of "unemployment" to the state of "economic inactivity" in a given period.

At the same time, there are three additional probabilities, expressing the degree of stability of each of the three states (employment, unemployment and economic inactivity) in given period:

- Pee - probability an employed person to maintain their state of employment in a given period;

- Puu- probability an unemployed person to remain unemployed in a given period; 
- Pnn - probability an economically inactive person to remain part of the inactive population in a given period.

The probabilities of transition between the different states on the labor market $\mathrm{Pij}$ for each period are estimated as follows:

$$
P i j=\frac{F i j}{\sum F i k}
$$

where Fij is the number of persons who in year $t$ are in a state of $i$, and in year $t+1$ in a state of $j$ where $i, j$ and $\mathrm{k}=\{\mathrm{e}, \boldsymbol{u}, \boldsymbol{\Pi}\}$.

If we mark the matrix of all transition probabilities with $\mathrm{T}$, then:

$$
\mathrm{T}=\left|\begin{array}{lll}
\text { Pee } & \text { Peu } & \text { Pen } \\
\text { Pue } & \text { Puu } & \text { Pun } \\
\text { Pne } & \text { Pnu } & \text { Pnn }
\end{array}\right|
$$

As in the transitional matrix, the sum of the probabilities in each row is 1 , then we have a total of six independent probabilities of transition. Then if the vector $\mathrm{St}=(\mathrm{Et}, \mathrm{Ut}, \mathrm{Nt})$ contains the number of the employed, the unemployed and the persons outside the labor force at the time $t$, we get the following equation:

$$
\mathrm{S}_{\mathrm{t}+1}=\mathrm{S}_{\mathrm{t}} \cdot \mathrm{T}
$$

Based on the transitional probabilities the matrix T expresses the motions of the individuals to and from the three main states - employment, unemployment and economic inactivity. Assuming that the matrix of transitional probabilities stays unchanged over time to reach equilibrium and we start with time 0 , then we get:

$$
\mathrm{S}_{\mathrm{m}+1}=\mathrm{S}_{\mathrm{O}} \cdot \mathrm{T}^{\mathrm{m}}
$$

From the theory of the stochastic Markov chains is known that if all the probabilities for transition are positive, then there is an equilibrium distribution by states $u$, such that: $u=u^{*} T$. The vector $\theta=(E, U, N)$ is a single eigenvector corresponding to the matrix $\mathrm{T}$. Then we can calculate the equilibrium unemployment rate, where:

$$
\mathrm{u}=\frac{\mathrm{U}}{(\mathrm{E}+\mathrm{U})}
$$

In our calculations, we use an equivalent approach to calculate this ratio. It is known that under certain conditions a direct correlation between the probabilities of transition and the indicator for equilibrium unemployment rate can be drawn.

Equilibrium in the labor market is defined as a state where the number of employed and the number of unemployed persons remain unchanged over time. In this case, the number of the employed persons who drop out from the labor force and those who lose their jobs and become part of the contingent of the unemployed persons, is equal to those unemployed persons and persons outside the labor force who find jobs. Therefore, the following equality is in force:

$$
(\text { Peu }+ \text { Pen }) . E=\text { Pue.U }+ \text { Pne.N }
$$

Given that over a certain period, the number of the unemployed persons who find jobs or become part of the population outside the labor force is equal to the number of those losing their job plus the number of persons outside the labor force who are unemployed, we have:

$$
(\text { Peu }+ \text { Pun }) . U=\text { Peu.E }+ \text { Pnu. } N
$$

If we multiply the first equation by Pnu, and the second with Pne and subtract the second from the first, we get:

$$
\text { (Pue.Pnu).U - (Peu.Pne)E = E.(Pne + Peu).Pnu - U(Pue + Pun).Pne }
$$


As we noted above, the unemployment rate is estimated from the cross human aggregations as follows:

$$
\mathrm{u}=\frac{\mathrm{U}}{(\mathrm{E}+\mathrm{U})}=\frac{1}{1+\left(\frac{\mathrm{E}}{\mathrm{U}}\right)}
$$

Therefore, we can express the ratio $\mathrm{E}$ by the probabilities of transition:

$$
\frac{\mathrm{E}}{\mathrm{U}}=\frac{(\text { Pue.Pnu })+(\text { Pue }+ \text { Pun }) \cdot \text { Pne }}{\text { (Peu.Pne })+(\text { Pen }+ \text { Peu }) \cdot \text { Pnu }}
$$

Therefore, we get a result representing the unemployment rate by the transitional probabilities of the labor market:

$$
\mathrm{u}=\frac{1}{1+\frac{\text { (Pue.Pnu })+(\text { Pue }+ \text { Pun }) \cdot \text { Pne }}{(\text { Peu.Pne })+(\text { Pen }+ \text { Peu }) \cdot \text { Pnu }}}
$$

An obvious result of the last expression is that the increase of the probability of transitions Peu, Pen and Pnu affects the growth of the unemployment rate, while the increase in the probabilities Pue, Pun and Pne impacts the decrease of this rate.

Assuming that the matrix of the transitional probabilities remains unchanged, we will use the last formula to estimate the equilibrium unemployment rate in each of the studied annual periods.

The main objective of the so presented approach and the estimations made by it is to achieve a better understanding of the transitions between employment, unemployment and economic inactivity. Such an approach allows the calculation of the probability that a person goes into a certain state on the labor market in a given period of time as a function of their state in another period of time in the past. In this case, we are trying to answer the question whether the probability of being unemployed in a given period of time depends on the occupied state on the labor market (employment, unemployment, economic inactivity) in other period of time in the past. The approach used allows evaluating the dependence of the state, thereby providing additional information about the characteristics and the tendencies in the labor market, as well as some of the key factors that form them (Terziev, Kanev, 2019; Terziev, 2019a-k).

The conceptual apparatus describing the employment and unemployment, currently remains at a stage of development. Two main reasons can be pointed out for this: In the first place, the long isolation of the Bulgarian science from the global economics, as well as the lack of access to the numerous "western" studies in the field of the labor market theory have exercised a certain influence. In the second place, the transition state of the Bulgarian economy, when many economic relations acquire "surrogate" character, includes both elements typical of the market economy, and remains of the planning and distribution paradigm.

The majority of the Bulgarian researchers adhere to the so-called broad interpretation of the "labor market" concept. This concept is understood as "a system of social relations, social norms, institutes providing reproduction, exchange and use of labor". The supporters of the broader approach include in the labor market the relations concerning employment of persons who seek jobs, the reproduction of the labor potential (education and training), as well as the field of use of labor (referring to this area, for example: personnel management in production). On this basis, it is concluded that the labor supply coincides with the concept of economically active population and the demand is equal to the total number of people employed in the economy (occupied jobs) and the job vacancies.

Accordingly, under „employment policy“ actually is understood policy affecting the total number of employed persons and jobs, as well as the factors that affect their formation and use. All mechanisms in the labor market operate in terms of a particular employment policy, which components cover all levels of economic management. At the same time, the researchers consider the employment policy itself (in the above meaning) as part of the social policy, but the employment policy has been and remains a key link in the social policy.

Basically, in order to justify the „broad“ approach to the labor market and employment policy, the following arguments are adduced. In the first place, the ratio between the employed and the unemployed provides a numerical preponderance of the employed in the ratio of $6: 1$. Accordingly, it is assumed that the achievement 
of effective employment of those who have jobs is more important than the fight against unemployment. Thus, characterizing the contemporary government policy, we can hear that "the employment policy is essentially brought to the reduction of the mass unemployment". In the second place, this shows the presence of serious problems and contradictions in the labor field. A characteristic feature of the labor market in Bulgaria is the hypertrophied development of its hidden part, consisting of hidden unemployment and hidden informal employment. In the third place, this is a combination of a number of "unearned" factors (economic, financial, demographic, social, etc.) affecting the formation and use of the labor potential, on the level and ratio of employment, often outside the range of vision of the public officials, responsible for political decisions.

We should not question features of the modern employment in Bulgaria, such as the sustainable high level of economic activity of the population, the insufficient use of qualification and intellectual potential (invisible part-time employment), the archaic, in terms of modern standards, sectoral and professional employment structure and many others. Based on this, the efforts to find ways to integrate the solutions of these and many other problems in all aspects of the policy implemented by the state, to include references in all activities of the employment field, are understandable. The inclusion of the problems of the employment in every aspect of the state policy is one of the main features of the socio-oriented economy, as well as the placing of a common goal - to achieve full, freely chosen and productive employment. We should note that the "principle of employment" as a benchmark for the social development, which the economic interests are largely subject to, was adopted by the global "market" society long time ago. The desire to make the economic development more socially orientated is usually embodied in the national employment strategies, which are generally implemented through public policy and by its components. The strategy is associated with a purposeful development, while the "policy" in this context is understood in its practical importance. In order to avoid terminological confusion, under the term "policy" below in the text we will understand the combination of particular measures and actions to achieve a preliminary determined result (Terziev, 2019ak).

\section{Based on this definition, we can identify the following features of the policy.}

Firstly, the policy has to be specific. Its objectives, defining what exactly is to be achieved in terms of effect and final result, have to be clearly determined, preferably to be evaluated in terms of quantity as well.

Secondly, the policy has to be implementable, i.e. the actions carried out within its framework, developed in accordance with its objectives, have to be supported by the relevant resources and associated with the institutions that implement this policy. The institutions themselves have to be able to implement the policy.

Thirdly, the policy must have a specific subject of influence (problem, population group, etc.). Moreover, clarity is necessary on the fact that namely the actions within a given policy are able to solve or mitigate the problem.

Fourthly, the policy has to be effective, i.e. to achieve specific maximum results by minimal resources.

If we stick to the applicable definition of the term „politics“, then the usually used in the Bulgarian economics term „employment policy“ in its broad interpretation, is appropriate to be considered to a certain extent as a synonym of the term "strategy". Then "the policy of the labor market" becomes, along with the other policies (macroeconomic, educational, tax, investment, etc.), an integral part of the national employment strategy in which, regardless of the basic profile of the policy, the actions in each direction are planned, implemented and evaluated in accordance with the general strategic orientations.

From the entire diversity of relations that arise between the employer and the employee, the attention is focused on those aspects of the functioning of the labor market and the impact on it by the state, which are directly related to employment of the unemployed persons and the occupation of the job vacancies. In this aspect under labor market, we will mean a place where the employee seeking employment and the employer seeking employees meet to start collaboration. Therefore, in this segment of the labor market there are only citizens (having a job, but changing it, unemployed and other inactive) who are in a state of job search. Those who have a job and are not looking for a new one, as well as non-working citizens who do not make efforts to seek employment, are outside the labor market. On the other hand, not everybody who has a job will be deemed represented on the labor market, but only the part of job vacancies (or potentially available jobs) that the employers present on this market in order to hire the necessary employees for them. The main task of the employee in the labor market is to find a suitable job, i.e. a job that meets their own assessment of their professional and other business skills, for the desired salary and working conditions (including working time), prestige, etc. The main task of the employer in the labor market is to find a suitable employee for the job vacancy, i.e. an employee who meets best the functional content of the job for an acceptable salary and other working conditions. In case they meet an agreement, the employee and the employer, after 
the conclusion of a deal in the form of employment contract, leave the labor market. The labor market provides jobs for the employees and employees to the employers and coordinates solutions in the field of employment.

Usually, an internal and external labor markets are distinguished. On the internal or inter-company labor market rules that regulate the employment (transfer) of employees within the enterprise, are created. In future, we will mean only the external labor market, where all the employees, job seekers and employers (jobs), seeking employees are (Terziev, 2019a-k; Terziev, 2018-d; Terziev, Georgiev, 2018e-f; Terziev, Arabska, 2014; Terziev, 2015-b; Terziev, Arabska, 2016a).

A simplified model of the interaction between the employee and the job position of the labor market can be introduced schematically (Fig.2).

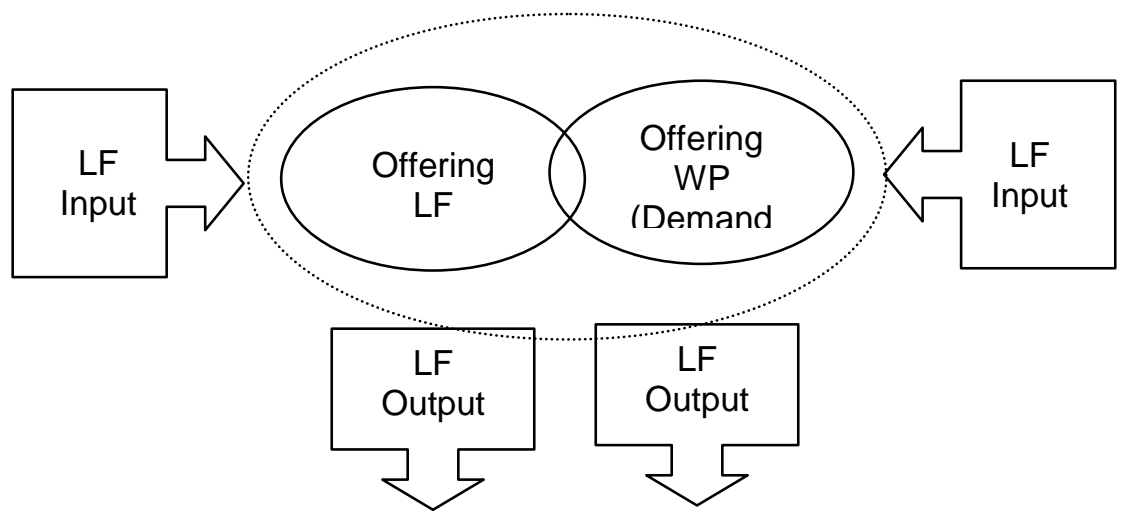

Figure.2. Simplified model of functioning of the labor market

The labor supply on the labor market is the combination of employees seeking employment. The labor demand (or supply of jobs) is the combination of job vacancies that will be occupied by employees. Employees seeking employment (entry or inflow of labor force), as well as new jobs, which require employees (inflow of job positions) appear in every period on the labor market. In every period however, employees and job positions leave the market as well (exit or outflow of labor force and job positions). Therefore, the labor supply and demand in the labor market can be presented in the following form:

In terms of the effectiveness of the process of employment and occupation of job vacancies, a key task of the external labor market is to minimize the time spent, necessary to find a contracting party on the labor market and to conclude an employment contract. The opportunities to reduce the time depend on a number of causalities. In order to identify the main factors that affect the effectiveness in the selection of jobs and employees, it is appropriate to resort to the theoretical construction of the "ideal" or "purified" labor market. Based on these correlations, an "ideal" or "purified" market may be considered a labor market, where:

- The labor supply (the number of employees present on the labor market) is equal to the labor demand (the number of jobs present on the labor market).

- The period from the appearance of the employee on the labor market (job vacancies) to the contraction of an employment contract (period of demand) is extremely short. In other words, the conclusion of the employment contract occurs at the time when the employee and the job position appear on the labor market (the point of entry coincides with the point of exit).

- All employees and job vacancies leave the labor market effectively, i.e. only due to the conclusion of an employment contract.

If these conditions are fulfilled, then:

The entry of Labor force $(L F)=$ the supply of LF $=$ the exit of LF $=$ the entry of Job position $(J P)=$ the supply of JP - the exit of JP = the number of concluded labor contracts (employment).

\section{CONCLUSION}

However, even the most organized labor markets are far from ideal conditions. In the first place, the labor supply usually does not match with the supply of job positions. Along with the quantitative differences, there are also significant structural differences (vocational, geographical, sectoral, etc.). In the second place, the inflows on the labor market are not equal to the outflows of job positions. In the third place, from the moment of appearance of the employee (the job position) on the labor market to the conclusion of an employment 
contract a certain time passes (for some employees and job positions this period is significantly longer). The period for finding employees and job positions on the labor market in general does not coincide and is contrary to individual groups. In the fourth place, the outflow of the labor force does not coincide with the volume of inflow of job positions, and the outflow itself is not always effective (related to employment). The employee can leave the labor market and at the same time the labor force due to the loss of hope of finding a job. The job vacancy may also be excluded from the labor market, e.g. due to its closure (Terziev, Arabska, 2014; Terziev, 2015-b; Terziev, Arabska, 2016a).

\section{REFERENCE LIST}

Georgiev, Marin. (2016). Obshtestvenoto i ikonomichesko razvitie v konteksta na sotsialnite politiki. // Spisanie za nauka "Novo znanie“. Visshe Uchilishte po Agrobiznes i Razvitie na Regionite, 5, 2016, N 4, str. 26-41, ISSN 2367-4598 (Online), (Print) ISSN 1314-5703 (Георгиев, Марин. Общественото и икономическо развитие в контекста на социалните политики. // Списание за наука „Ново знание“. Висше училище по агробизнес и развитие на регионите, 5, 2016, N 4, стр. 26-41, ISSN 2367-4598 (Online), (Print) ISSN 1314-5703.

Georgiev, Marin. (2017). Sbalansirovannaya karta kak alyternativa malogo biznesa. // Innovatsionnie tehnologii v nauke novogo vrmeni, Sbornik statey Mezhdunarodnoy nauchno - prakticheskoy konferentsii 1 fevralya 2017 g., Ufa NITS AETERNA, Chasty 1, 2017, s. 43-49, ISBN 978-5-00109004-5, ISBN 978-5-00109-007-6 (Георгиев, Марин. Сбалансированная карта как альтернатива малого бизнеса. // Инновационніе технологии в науке нового врмени, Сборник статей Международной научно - практической конференции 1 февраля 2017 г., Уфра НИЦ АЭТЕРНА, Часть 1, 2017, с. 43-49, ISBN 978-5-00109-004-5, ISBN 978-5-00109-007-6).

Georgiev, Marin. (2017a). Impacts of active social programs on labor market. // Mezhdunarodnayy nauchnayy zhurnal „Innovatsionnaya nauka“. NITS Aeterna, N 02-1, 2017, pp. 139-143, ISSN 24106070 (Georgiev, Marin. Impacts of active social programs on labor market. // Международный научный журнал „Инновационная наука“. НИЦ Аэтерна, N 02-1, 2017, pp. 139-143, ISSN 24106070).

Terziev, V., Kanev, D. (2019). Modern developments in behavioral economics. // Smart Technologies and Innovations in Design for Control of Technological Processes and Objects: Economy and Production Proceeding of the International Science and Technology Conference „FarEastCon-2018” Volume 138, October 2-4, 2018, Vladivostok, Russian Federation, pp. 10-23, 2019, (Print) ISBN978-3-030-15576-6, (Online) ISBN978-3-030-15577-3.

Terziev, Venelin. (2019a). Provision of integrated employment and social assistance services in Bulgaria. // Smart Technologies and Innovations in Design for Control of Technological Processes and Objects: Economy and Production Proceeding of the International Science and Technology Conference „FarEastCon-2018” Volume 138, October 2-4, 2018, Vladivostok, Russian Federation, pp. 24-39, 2019, (Print) ISBN978-3-030-15576-6, (Online) ISBN978-3-030-15577-3.

Terziev, Venelin. (2019b). Problems of control in the social sphere. // INTCESS 2019- $6^{\text {th }}$ International Conference on Education and Social Sciences, 4-6 February, 2019, Dubai, International Organization Center of Academic Research, Istanbul, Turkey, pp. 577-593, ISBN: 978-605-82433-5-4.

Terziev, Venelin. (2019c). The criterion "competence” in the economic sector. // INTCESS 2019- $6^{\text {th }}$ International Conference on Education and Social Sciences, 4-6 February, 2019, Dubai, International Organization Center of Academic Research, Istanbul, Turkey, pp. 1241-1247, ISBN: 978-605-824335-4.

Terziev, Venelin. (2019d). Social policy and labor market development in Bulgarian transition period. // INTCESS 2019- $6^{\text {th }}$ International Conference on Education and Social Sciences, 4-6 February, 2019, Dubai, International Organization Center of Academic Research, Istanbul, Turkey, pp. 703-714, ISBN: 978-605-82433-5-4.

Terziev, Venelin. (2019e). Theoretical basis of development of labor market and social policy in the republic of Bulgaria. // INTCESS 2019- $6^{\text {th }}$ International Conference on Education and Social Sciences, 4-6 February, 2019, Dubai, International Organization Center of Academic Research, Istanbul, Turkey, pp. 
715-726, ISBN: 978-605-82433-5-4.

Terziev, Venelin. (2019f). The problem of social efficiency- Indicators for social efficiency. // INTCESS 2019$6^{\text {th }}$ International Conference on Education and Social Sciences, 4-6 February, 2019, Dubai, International Organization Center of Academic Research, Istanbul, Turkey, pp. 669-678, ISBN: 978605-82433-5-4.

Terziev, Venelin. (2019g). Experiencing social policy development and efficiency measurment. // INTCESS 2019- $6^{\text {th }}$ International Conference on Education and Social Sciences, 4-6 February, 2019, Dubai, International Organization Center of Academic Research, Istanbul, Turkey, pp. 679-686, ISBN: 978605-82433-5-4.

Terziev, Venelin. (2019h). Efficiency and assessment of social technology. // INTCESS 2019- $6^{\text {th }}$ International Conference on Education and Social Sciences, 4-6 February, 2019, Dubai, International Organization Center of Academic Research, Istanbul, Turkey, pp. 687-694, ISBN: 978-605-82433-5-4.

Terziev, Venelin. (2019i). Conceptual framework of social adaptation. // INTCESS 2019- $6^{\text {th }}$ International Conference on Education and Social Sciences, 4-6 February, 2019, Dubai, International Organization Center of Academic Research, Istanbul, Turkey, pp. 494-503, ISBN: 978-605-82433-5-4.

Terziev, Venelin. (2019j). The dependence social adaptation- socialization. // INTCESS 2019- th $^{\text {th }}$ International Conference on Education and Social Sciences, 4-6 February, 2019, Dubai, International Organization Center of Academic Research, Istanbul, Turkey, pp. 478-485, ISBN: 978-605-82433-5-4.

Terziev, Venelin. (2019k). Social activity and human resources as social development factors. // INTCESS 2019- $6^{\text {th }}$ International Conference on Education and Social Sciences, 4-6 February, 2019, Dubai, International Organization Center of Academic Research, Istanbul, Turkey, pp. 546-553, ISBN: $978-$ 605-82433-5-4.

Terziev, Venelin. (2018). The active model of a social programme and its strategic advantage . // ADVED 2018- $4^{\text {th }}$ International Conference on Advances in Education and Social Sciences Abstracts \& Proceedings, 15-17 October 2018- Istanbul, Turkey, International Organization Center of Academic Research, www.ocerints.org, Istanbul, Turkey, 2018, pp. 189-203, ISBN: 978-605-82433-4-7.

Terziev, Venelin. (2018a). Active social programs development in Bulgaria: contemporary challenges and social management instruments. // ADVED 2018- $4^{\text {th }}$ International Conference on Advances in Education and Social Sciences Abstracts \& Proceedings, 15-17 October 2018- Istanbul, Turkey, International Organization Center of Academic Research, www.ocerints.org, Istanbul, Turkey, 2018, pp. 149-163, ISBN: 978-605-82433-4-7.

Terziev, Venelin. (2018b). Social assistance services and integrated employment in Bulgaria. // ADVED 2018- $4^{\text {th }}$ International Conference on Advances in Education and Social Sciences Abstracts \& Proceedings, 15-17 October 2018- Istanbul, Turkey, International Organization Center of Academic Research, www.ocerints.org, Istanbul, Turkey, 2018, pp. 164-177, ISBN: 978-605-82433-4-7.

Terziev, Venelin. (2018c). Impact of the labor market policies for ensuring employment. // ADVED 2018- $4^{\text {th }}$ International Conference on Advances in Education and Social Sciences Abstracts \& Proceedings, 1517 October 2018- Istanbul, Turkey, International Organization Center of Academic Research, www.ocerints.org, Istanbul, Turkey, 2018, pp. 178-188, ISBN: 978-605-82433-4-7.

Terziev, Venelin. (2018d). Importance of human resources to social development. // ADVED 2018-4th International Conference on Advances in Education and Social Sciences Abstracts \& Proceedings, 1517 October 2018- Istanbul, Turkey, International Organization Center of Academic Research, www.ocerints.org, Istanbul, Turkey, 2018, pp. 204-212, ISBN: 978-605-82433-4-7.

Terziev, V., Georgiev, M. (2018e). A strategic framework for the development of social entrepreneurship in Bulgaria. // Knowledge - International Journal, August 2018, Institute of Knowledge Management, Skopje, Macedonia, 25, 2018, N 1, pp. 23-34, ISSN 1857-923X (for e-version), ISSN 2545 - 4439 (for printed version).

Terziev, V., Georgiev, M. (2018f). Support for the development of social entrepreneurship in Bulgaria. // Knowledge - International Journal, September, 2018, Institute of Knowledge Management, Skopje, Macedonia, 26, 2018, N1, pp.57-74, ISSN 1857-923X (for e-version), ISSN 2545 - 4439 (for printed version).

Terziev, V., E., Arabska. (2014). Assessment of active social policies' impacts on labor market in the Republic of Bulgaria. Kolektivnaya monografiya "Sotsialyno-ekonomicheskie i pravovay razvitiya 
ekonomiki“, Ufa, Aeterna. Rossiya, 2014. ISBN 978-5-906769-97-8, str. 3-57 (Terziev, V., E. Arabska. (2014). Assessment of active social policies' impacts on labor market in the Republic of Bulgaria. Колективная монография „Социально-экономические и правовы развития экономики“, Уфа, Аэтерна. Россия, 2014. ISBN 978-5-906769-97-8, стр. 3-57).

Terziev, Venelin. (2015). Impact of active social policies and programs in the period of active economic transformations in Bulgaria, „East West”Association for Advanced Studies and Higher Education,Vienna, 2015, ISBN 78-3-903063-44-0, 434 p.

Terziev, Venelin. (2015a). Assessment of active social policies impact of social policies on transformation processes in bulgarian economy, Moscow, 2015, Publisher „Перо“, 110 p.

Terziev, Venelin. (2015b). Opportunities for improving the efficiency of the social adaptation of servicemen discharged from military service in Bulgaria:- Novosibirsk: Publisher CRNS, 2015. ISBN 978-5-00068402-3, $270 \mathrm{p}$.

Terziev, V., E., Arabska. (2016a). Effektivnoe vliyanie na raynok truda posredstvom uluchsheniya realizatsii sotsialynoy politiki. Novosibirsk: Izdatelystvo TSRNS, 2016. ISBN 978-5-00068-496-2, $312 \mathrm{str}$ (Терзиев, В., Е. Арабска. (2016а). Эфрфективное влияние на рынок труда посредством улучшения реализации социальной политики. Новосибирск: Издательство ЦРНС, 2016. ISBN 978-5-00068-496-2, 312 стр). 